DOI: $10.31249 / \mathrm{rsm} / 2018.04 .14$

\title{
M.А. Фельдман
}

\section{КЕМ БЫАА ОАЕРЖАНА ПОБЕАА? К ВОПРОСУ О РЕЗУАЬТАТАХ АИСКУССИИ НА ИЮАЬСКОМ (1928 Г.) ПАЕНУМЕ ЦК ВКП (6)}

Аннотация. Критика капиталистических отношений в современной России отразилась и на представлениях историков о НЭПе: налицо нарастание пессимистических выводов об отсутствии альтернатив сталинскому варианту сочииальноэкономического развития СССР. В статье отстаивается иная точка зрения: утверждается, что в работах экономистов и работников Госплана 1927-1928 г2. содержались идеи разумной модернизации странь на основе смешанной экономики. Июльский пленум ЦК ВКП (б) продемонстрировал реальную альтернативу «левому курсу» - проект индустриализачии страны и трансформаџии крестьянского хозяйства на принципах новой экономической политики.

Ключевые слова: ВКП (б), июльский пленум, НЭП, СССР, индустриализация, коллективизациия.

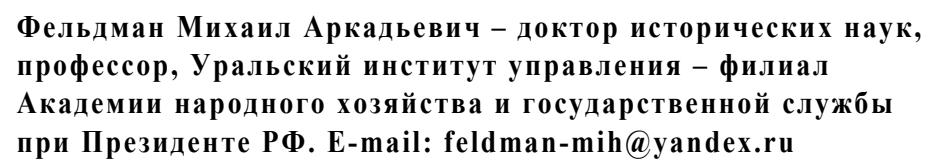

M.A. Feldman. Who Won? On the Question about the Results of the Discussion at the July (1928) Plenum of the Central Committee of the AllUNION Communist Party (B)

Abstract. The article argues that the State plan of 1927-1928, prepared by economists and employees, envisioned a substantial modernization of the country on the basis of the mixed economy. The July (1928) Plenum of the CPSU Central Committee (b) demonstrated a real alternative to the "left course» - a variant of the country's industrialization and transformation of the peasant economy on the principles of the new economic policy.

Keywords: VKP (b), the July Plenum, the NEP, USSR, industrialization, collectivization. 


\title{
ФЕНОМЕНОЛОГИЯ СОВЕТСКОГО ОБЩЕСТВА
}

\author{
Feldman Mihail Arkad'evich - Doctor of Historical Sciences, \\ Professor, Ural Institute of management-branch \\ of Russian presidential Academy of national economy \\ and public administration. E-mail: feldman-mih@yandex.ru
}

В исторической литературе Июльский (1928) пленум ЦК ВКП (б) обычно рассматривался в контексте борьбы с «правой оппозицией». Однако уже в самом начале 1990-х годов французский историк Н. Верт в книге «История советского государства» отметил, что участники Апрельского и Июльского (1928) пленумов не подержали курс Сталина на «чрезвычайные меры» по отношению к зажиточным крестьянам. В резолюциях, принятых на пленумах, осуждались перегибы по отношению к частным предпринимателям и середнякам [1, с. 182-183]. Даже с учетом того, что соответствующий раздел книги Верта в духе советской традиции назывался «разгром правой оппозиции», из текста вытекало, что речь идет о столкновении двух течений в руководстве большевистской партии.

Насколько глубоко разногласия в трактовках НЭПа и дальнейших путях развития проникли в партийные массы к лету 1928 г.?

Не давая прямого ответа на этот вопрос, Р. Такер, указывая на предельную внутреннюю напряженность полемики на Июльском пленуме, отмечает: апелляция Сталина к антикулацким настроениям в партии, с весьма произвольным использованием ленинских цитат, была с пониманием воспринята частью коммунистов в центральных управленческих ведомствах Советского государства [12, с. 372-373]. О поддержке курса Сталина со стороны части среднего звена партийного аппарата Сибири пишет С.А. Кислицын [6, с. 121].

Однако и взгляды сторонников нэпа имели немалую поддержку в партии, подчеркивает Е.Г. Гимпельсон. Острота дискуссий на пленумах была во многом связана с экономическим кризисом и затруднением экспортной деятельности. Кризис потребовал ответа на жесткие вопросы: «кто в нем виноват и как из него выйти»? [2, с. 153].

Судьба Июльского пленума, по мнению венгерского историка М. Куна, решалась в двух плоскостях. В ходе открытых дискуссий, где А.И. Рыкову и Н.И. Бухарину удалось отстоять курс НЭПа. А вот в другой плоскости - организаторской - противники Сталина, ради ложно понятого единства партии, не решились на развернутую критику Генерального секретаря ЦК, предоставив Сталину возможность осуществления изощренных закулисных действий по удалению оппонентов из управленческого аппарата [5, с. 235-236].

Вышедшее в свет в 2000 г. «Введение» ко второму тому пятитомника «Как ломали НЭП» [3], написанное историками В.П. Даниловым, А.Ю. Ватлиным и О.В. Хлевнюком, и на сегодняшний день представляет собой самый глубокий анализ событий политической полемики на Июльском пленуме. 
Авторы «Введения» не признавали хрупкость и формальность победы группы Рыкова-Бухарина по центральному вопросу повестки пленума, но вместе с тем отмечали: его резолюции на сохранение НЭПа, прежде всего установки на подъем мелких и средних индивидуальных крестьянских хозяйств, на широкое использование и развитие товарно-рыночных связей в экономике - были поддержаны участниками партийного форума [3, с. 14].

Усиление критических подходов к развитию капиталистических отношений сказалось и на эволюции оценок нэпа историками. В оценках этого явления стал преобладать пессимизм, неверие в возможность альтернативы сталинскому варианту социально-экономического развития. Так, В.В. Кондрашин пишет: «Изучив значительный комплекс архивных источников и опубликованных материалов, я пришел к выводу о невозможности осуществления на практике программы “правой оппозиции" и, таким образом, нереальности "бухаринской альтернативы” сталинской насильственной коллективизации. Именно поэтому победа Сталина в борьбе за власть была вполне закономерной» [7, с. 22].

Следует учесть, что В.В. Кондрашин солидаризуется с лидерами «правой оппозиции» - они «совершенно справедливо критиковали сталинистов за их приверженность методам насилия в обращении с крестьянством». Более того, отмечает историк, «их критика “чрезвычайщины” во время хлебозаготовительных кампаний 1928 и 1929 гг. давала свои результаты, поскольку на официальном уровне осуждались и исправлялись так называемые перегибы на местах». Наконец, ставка группы Рыкова-Бухарина «на развитие индивидуальных крестьянских хозяйств как наиболее перспективных на ближайшее десятилетие с точки зрения обеспечения государственных нужд», вызывает доверие автора [там же].

Нереалистичность позиций правых, по мнению Кондрашина, связана с содержанием их предложений по практическому выходу страны из сложившейся ситуации. К ним историк относит «снижение взятых темпов индустриализации, отказ от проведения индустриализации любой ценой, перераспределение имеющихся у государства средств, прежде всего валютных, на нужды населения, переживающего серьезные продовольственные трудности в городе и на селе» [7, с. 23].

Однако при этом Кондрашин ссылается на выступления сторонников группы Рыкова-Бухарина на более позднем, 1929 г., пленуме ЦК, т.е. на события, происходившие уже в совершенно иной политической ситуации.

Пленум 4-12 июля 1928 г. стал местом обширной дискуссии, внешне умеренной - по эмоциональному напряжению, однако упорной и ожесточенной - по внутреннему содержанию выступлений. 
На экономическую и политическую ситуацию летом 1928 г. влиял ряд весьма разнонаправленных факторов. Во-первых, многие ученые-экономисты на страницах научных журналов [13, с. 26], в ходе дискуссий съездов работников госпланов [10, с. 3-5] пришли к выводу о том, что путь к социализму лежит через «развертывание товарно-денежного оборота, позволяющего мобилизовать все хозяйственные силы», через сохранение многоукладной экономики. Эти мысли легли в основу проектов Первого пятилетнего плана, создавая определенное новаторское научное сознание, оказавшее влияние на выступления участников Апрельского (1928) пленума, на становление течения сторонников сохранения рациональных принципов регулирования экономики. Это означало, что часть большевистской элиты (даже при наличии внутренней цензуры) оказалась способной к эволюции своих взглядов, к восприятию элементов научного ви́дения экономики и социального развития без приоритета насилия.

Во-вторых, резолюции Апрельского пленума нацеливали на продолжение НЭПа как наименее конфликтного и наиболее эффективного пути модернизации страны, или, используя выражение В.П. Данилова, - «единственно реальной политики, направленной на возможно более быстрое развитие разных форм сельской кооперации от первичных форм сбытовых и закупочных до подлинно производственных» [4, с. 17].

В-третьих, на мировоззрение советского руководства оказывали влияние догмы марксистской идеологии, связанные с отрицанием рыночной экономики и частной собственности, а также курс на «мировую революцию», нашедший выражение в деятельности Коминтерна. Это обусловило своеобразную политику И.В. Сталина и той части партии, которая готова была «сохранить нэп, но без нэпманов» [8, с. 426]. В-четвертых, сказывалась острая необходимость изыскания значительных финансовых средств для закупок импортного промышленного оборудования.

Наконец, обсуждение жизненно важных проблем на пленумах 1928 г. проходило в рамках той партии, которая настороженно относилась к любой дискуссии в принципе, особенно после четырех лет внутрипартийной борьбы с троцкистской оппозицией. Для Сталина, шаг за шагом укреплявшего личную власть, обсуждение острых вопросов было допустимо лишь в пределах поддержки позиции Генерального секретаря ЦК.

Показательный момент: противостояние сторонников и противников НЭПа до и после Апрельского пленума приводило к появлению разного рода циркуляров противоречивого характера, вносящих сумятицу в умы региональных руководителей $[3$, с. 18,20$]$. Одновременно продолжал раскручиваться запущенный в декабре 1927 г. механизм «чрезвычайных мер», демонстрировавший способность авторитарного режима к функционированию вне установленного правового поля. 
В такой ситуации Июльский (1928) пленум превращался не только в дискуссионную площадку: сверку позиций сталинцев и приверженцев главы СНК и СТО А.И. Рыкова. Вопрос о самой допустимости применения систеMbl «чрезвычайных мер», в зависимости от ее принципиальной оценки, мог из конкретного и тактического стать стратегическим и судьбоносным для правящей партии.

Обращает на себя внимание выстроенная Сталиным композиция Июльского пленума: если в апреле критический «запал» членов ЦК, осуждающих применение «чрезвычайных мер», по замыслу генерального секретаря, должен был быть «погашен» дружным осуждением «буржуазных специалистов»«шахтинцев», то в июле 1928 г., уже на первом заседании, обсуждение вопросов Коминтерна должно было зарядить участников пленума леворадикальными настроениями.

В определенной степени Сталину это удалось. Как справедливо отмечают современные историки, в докладе Н.И. Бухарина «Программа Коммунистического интернационала» доминировала жесткая и бескомпромиссная линия по отношению к европейской социал-демократии, на «мерзости» которой списывались все неудачи самих коммунистов. Кроме того, Бухарин настаивал на близости и неизбежности новых войн с участием СССР. Обострение международного положения весной 1927 г. позволило сплотить партийный аппарат в условиях противоборства с «объединенной оппозицией», а в дальнейшем - постоянно эксплуатировать идею военной опасности для поддержания в СССР обстановки «осажденной крепости» [3, с. 14].

Такой организационный маневр (выстраивание порядка проведения пленума) привел к тому, что первые четыре заседания Июльского пленума прошли по сценарию генерального секретаря.

Центральный вопрос - «Политика хлебозаготовок в связи с общим хозяйственным положением», - как и на Апрельском пленуме, начинался с постановочного доклада А.И. Микояна. Весь этот доклад пронизывала двойственность [там же]: нарком одновременно и осуждал применение «чрезвычайных мер» («мы должны решительно прекратить практику экстраординарных мер административного произвола и продразверсточных методов заготовки»), и высказывал одобрение применению насилия по отношению к крестьянам в ходе первых месяцев 1928 г. «Принятые Центральным Комитетом меры в январе... предотвратили опасность величайшего кризиса народного хозяйства, который неизбежно вытекал из кризиса хлебозаготовок», - говорил Микоян [8, с. 189, 194].

Двойственность обнаруживалась и в оценках существующего положения в экономике. Вопреки реальности, Микоян утверждал, что «основные рабочие центры более или менее обеспечены хлебом». Более того, по мнению наркома, «фактически мы имеем подъем сельского хозяйства» [8, с. 180-181]. 
Каким образом внезапно обнаруженный «подъем сельского хозяйства» сочетался с признанием самого Микояна: «Базой наших хлебозаготовительных затруднений является кризис нашего зернового хозяйства. Он выражается в том, что наше крестьянское хозяйство отстало, раздробленно, причем измельчание крестьянского хозяйства продолжается, что отражается не только на урожайности, но и на том, что чем больше раздроблено хозяйство, тем меньше товарность его продукции» [8, с. 187]? С признанием сохранения кризисной ситуации в производстве льна («после провала 1925/26 г. мы вот уже два года еще никак не можем выбраться из затруднений и изжить кризис льна»), ряда других сельскохозяйственных культур, срыва поставок на внутренний рынок и нарушением экспортных обязательств [5, с. 183-185]? Кроме желания приукрасить реальное положение в угоду Сталину, смягчить критику применения «чрезвычайных мер»- других объяснений нет.

Не спасали доклад наркома примеры проявления зимой 1928 г. случаев беззакония (повсеместного закрытия базаров, изъятия части страховых запасов у середняка и т.п.). Микоян признал: «Распространение практики этих мер на середняка ... кроет в себе величайшие политические и экономические опасности» [5, с. 192-194]. Однако, судя по выступлениям членов ЦК в прениях, это признание не успокоило присутствующих.

Тезис об обострении классовой борьбы во внешнеполитической сфере, судя по первому, «коминтерновскому», вопросу, сомнений у членов ЦК не вызывал. Однако предполагало ли это автоматическое перенесение подобной идеологической конструкции во внутриполитическую жизнь? В выступлении Сталина на Пленуме 9 июля 1928 г. содержался утвердительный ответ. Генеральный секретарь утверждал, «что по мере нашего продвижения вперед, сопротивление капиталистических элементов будет возрастать, классовая борьба будет обостряться, а советская власть, силы которой будут возрастать все больше и больше, будет проводить политику изоляции этих элементов, политику подавления сопротивления эксплуататоров...» [5, с. 360].

Само развитие социалистических форм хозяйства для Сталина априори означало вытеснение из экономики «тысяч и тысяч мелких и средних торговцев» и предпринимателей всех видов. Тезис о закономерном обострении классовой борьбы, обосновании неизбежности и необходимости применения административных «чрезвычайных мер» для «подавления сопротивления эксплуататоров», провозглашенный Сталиным на десятом заседании пленума, фактически дезавуировал все неоднократно повторяющиеся слова генсека о «необязательности чрезвычайных мер». Более того, как подчеркивал Сталин, «чрезвычайные меры необходимы и целесообразны при известных, чрезвычайных условиях, когда у нас нет в наличии других мер для маневрирования» $[5$, с. 361$]$. 
Как и на Апрельском пленуме, в июле 1928 г. одним из наиболее значимых стало выступление кандидата в члены Политбюро, Председателя СНК Украины В.Я. Чубаря. Чубарь основную причину недостатка хлеба видел не в сопротивлении кулачества («кулацкой стачке») а в малой товарности крестьянского хозяйства. «Основа - это малая товарность, причина к этому низкая урожайность... Я хочу здесь со всей решительностью подчеркнуть то положение, что партия, советская власть, местные органы и само крестьянство для повышения урожайности еще не сделали и десятой доли того, что нужно сделать» [5, с. 218].

Повысить урожайность, указывал Чубарь, мог только комплекс государственных мероприятий, включавший «создание семенных фондов чистосортных и улучшенных семян; производство удобрений; машинизацию, тракторизацию, а также кооперативное объединение бедняцких и середняцких хозяйств. Повышение урожайности в миллионах крестьянских хозяйств могло дать сразу дополнительные сотни миллионы пудов зерна». Чубарь критически оценил те положения доклада Микояна, в которых содержалась пренебрежительная оценка роли ценообразования на зерновые культуры, а также не соответствующая действительности картина поставок сельскохозяйственных машин в сельскую местность [5, с. 219-225]. Фактический вывод Чубаря заключался в том, что без повышения урожайности земли на экспорт зерновых культур рассчитывать трудно. «Я лично считаю, что на ближайший период в нашем экспортном плане зерновые продукты большого места не займут» $[5$, с. 220].

Выступивший вслед за Чубарем управляющий ЦСУ СССР В.В. Осинский (Оболенский) заострил внимание на диспропорции в расчетах между промышленностью и сельским хозяйством, возникшей из-за манипуляций с ценообразованием, выступил с осуждением масштабного перелива капиталов из легкой в тяжелую промышленность. Осинскому, возможно, простилось бы и многословие, и чрезмерное обилие статистических данных, и явная затянутость выступления. Однако, во-первых, управляющий ЦСУ СССР обратил внимание на то, что волюнтаристский подход к ценообразованию предлагался еще сторонниками объединенной оппозиции. Во-вторых, высказал ряд персональных замечаний «вождям» - Сталину и Молотову. В-третьих, осмелился указать на значительные ежегодные траты (несколько сотен миллионов рублей) на оплату поездок советских управленцев на курорты Крыма и Кавказа. В условиях острого дефицита госбюджета, по мнению Осинского, это была непозволительная роскошь [5, с. 225-234].

С учетом небольшого выступления И.И. Лепсе - председателя ЦК Союза металлистов, - заявившего о тяжелом продовольственном положении даже в ряде поселков при ведущих металлургических заводах Украины и Урала 


\section{ФЕНОМЕНОЛОГИЯ СОВЕТСКОГО ОБЩЕСТВА}

[5, с. 218], обсуждение доклада Микояна явно пошло по незапланированному сценарию.

Характерно, что оба выступивших сторонника Сталина, секретарь СевероКавказского крайкома А.А. Андреев и секретарь Нижне-Волжского крайкома Б.П. Шеболдаев, не подвергали критике фактическое содержание выступлений Осинского и Чубаря. «Нашей важнейшей задачей, - заявил Андреев, является повышение товарности сельского хозяйства, а поднимать эту товарность только через одни совхозы, через колхозы, которые мы должны теперь развивать более усиленно, мы не сможем. Вопрос усиленной товарности сельского хозяйства будет решать все же индивидуальное крестьянское хозяйство, а повысить товарность крестьянского хозяйства мы можем только через производственную сельскохозяйственную кооперацию, включая в кооперативный оборот раздробленные крестьянские хозяйства» $[5$, с. 238]. Шеболдаев отметил недостаточно тщательную проработку вопроса о ценах, нанесшую серьезный вред развитию крестьянского хозяйства [5, с. 240].

Тем не менее Андреев и Шеболдаев обвинили Осинского в некомпетентности и непозволительной для участника пленума вольности - критике партийного руководства. «В ЦК - не дураки сидят», - сообщил пленуму Андреев $[5$, c. 234,239$]$.

Шеболдаев в отрицательном отношении Осинского к чрезвычайным мерам в ходе хлебозаготовительной кампании увидел «неприятие курса партии» [5, с. 241]. Собственно говоря, это был первый «выстрел» на фоне кажущегося единства присутствующих: деловая и аргументированная критика руководства приравнивалась к оппозиционности.

Сигнал был услышан: новое, седьмое, заседание началось с выступления секретаря крайкома ВКП (б) Казахстана Ф.И. Голощекина, обвинившего Осинского в «неаргументированности выводов»; оратор заслужил одобрительную реплику Сталина. Голощекин оценил использование практики «чрезвычайных мер» как верное и необходимое, обусловленное «обострением классовой борьбы» [5, с. 243]. После такого признания логичным был следующий шаг: укор (пока без «ярлыков») был брошен всем противникам «чрезвычайных мер». «Я отрицательно отношусь к тем товарищам, которые сейчас на почве обострения наших отношений в деревне отрицательно относятся ко всей прошлой кампании», - заявил Голощекин [5, с. 242].

Не вступая в полемику с Голощекиным, А.И. Стецкий, ленинградский партийный работник, подверг критике доклад Микояна, обратив внимание на забвение в докладе резолюций Апрельского пленума, определивших, что «наши теперешние затруднения имеют своим источником нарушение рыночного равновесия между промышленностью и сельским хозяйством, имеют ошибки планового характера, которыми воспользовался кулак» [5, с. 245]. По словам Стецкого, явно несостоятельна была попытка Микояна объяснить 
применение «чрезвычайных мер» так называемыми объективными причинами. Выпячивание «объективных причин» (техническая и хозяйственная отсталость, и кризис зерновых культур, и раздробленность крестьянского хозяйства, и недостаток товарности сельского хозяйства и т.д.) фактически означало замалчивание ошибок руководства партии в ходе хлебозаготовительной кампании, грозящее не только возвращением к политике времен Гражданской войны, но и потерей доверия к партии не только середняков, но и части бедноты [5, с. 245-248].

Выступление представителя группы сторонников НЭПа не могло не вызвать ответа оппонентов. Сталинский выдвиженец М.М. Хатаевич фактически обвинил Стецкого в защите кулаков и в политической демагогии. Хатаевич обвинил Стецкого в территориальной удаленности от «натурального всамделишнего мужика» [5, с. 249].

Однако поддержка сталинского курса оказалась своеобразной: на примере Поволжья Хатаевич заявил о существующей возможности заготавливать зерно у кулаков «без применения экстраординарных мер» (!). Выдал партийный функционер и секрет Полишинеля: «чрезвычайные меры», повлекшие самые «резкие перегибы», местные партийные органы применяли под «нажимом ЦК». Так, уже после Апрельского пленума аппарат ЦК отправлял телеграммы с требованием усилить нажим на крестьян для обеспечения заготовок зерна [5, с. 250, 252]. Как видно, в июле 1928 г. принадлежность к «команде» еще не мешала переложить ответственность за ошибки на вышестоящие инстанции. Имя главного инициатора подобных телеграмм не прозвучало, но оно подразумевалось.

Седьмое и восьмое заседания Июльского пленума проходили с явным перевесом приверженцев НЭПа. Показательным можно считать выступление руководителя московской партийной организации Н.А. Угланова, указавшего на появление «тревоги и сомнений в рабочем классе на одиннадцатом году нашей революции» не только в силу продовольственного положения, но из-за определенной оторванности аппаратчиков от «партийной массы и широких рабочих масс». Одновременно Угланов отметил, что бюрократизация и излишняя централизация экономической жизни в СССР стали тормозом развития, а гонения на частных предпринимателей обернулись провалами в снабжении столицы [5, с. 254, 256].

Выступления других ораторов только дополняли картину в регионах частными деталями. Примечательной была реплика секретаря ЦК ВКП (б) Украины А.В. Медведева: максимальная концентрация всех сил партии на борьбу с оппозицией («идеологическую борьбу внутри партии») помешала тщательной подготовке хлебозаготовок [5, с. 290].

Выступление первого секретаря ЦК ВКП (б) Украины Л.М. Кагановича должно было переломить ход событий на пленуме. Начав с признания мас- 
штабных перебоев в снабжении рабочих центров и широкого недовольства среди крестьян-середняков «чрезвычайными мерами», вызванных объективными причинами - ошибками в планировании и отсутствием должного запаса промышленных товаров для торговли с селом, - Каганович представил «сопротивление кулаков» как главное препятствие на пути развития села в прошлом и настоящем. «Кулацкую стачку» можно было подавить только применением «чрезвычайных мер». Более того, утверждал Каганович, «чрезвычайные меры» вскоре понадобятся вновь: кулачество ведет войну против советской власти $[5$, с. 280-283]. Выразив в наиболее концентрированной форме позицию сторонников экстраординарных мер, Каганович выступил с прямой угрозой в адрес «инакомыслящих»: «Кто осуждает извращения, кто осуждает безобразия, которые были, не заостряя тут же вопрос о борьбе с кулаком, готовящимся сейчас с нами вступить в борьбу в предстоящую хлебозаготовительную кампанию, тот, по-моему, делает крупнейшую политическую ошибку, чреватую большими последствиями (курсив мой. - М. Ф.)» [5, c. 285].

Как видно, к концу восьмого заседания пленума сталинцы перешли к политическим обвинениям в адрес большой группы своих коллег. Затруднительной становилось не только «чистое» соревнование двух секторов в экономике, но и беспристрастная дискуссия по проблемам решения финансово-экономического развития.

Ответ на подобную позицию последовал довольно скоро. В своем выступлении глава советского правительства А.И. Рыков прямо заявил: «Мы зашли в применении чрезвычайных мер довольно далеко и теперь можем и должны подвести итоги пройденного. Я не могу похвастаться тем, что, применяя чрезвычайные меры, мы добились большого успеха» [5, с. 312].

Рыков выразил резкое несогласие с курсом на деформацию НЭПа: «Весь смысл речи Кагановича сводился к защите чрезвычайных мер как таковых, во все времена и при всяких обстоятельствах». Формально слова Рыкова были обращены к руководителю компартии Украины: «...из его речи вытекала сплошная апологетика (вместо анализа) этих самых чрезвычайных мер» [5, c. 310-311].

Естественно, все присутствующие на пленуме понимали, к кому в действительности обращены эти слова.

Как бы исследователи ни относились к Сталину, надо признать, что генсек прекрасно умел чувствовать обстановку, расклад сил и, в зависимости от этого, менять собственную тактику. Увидев критические выступления в свой адрес, Сталин предстал в роли мудрого и спокойного судьи, отвечающего на трудные вопросы. Оппоненты не из Политбюро (Осинский, Стецкий и др.) были выставлены Сталиным в качестве путаников («свалили в одну кучу разнообразные причины наших затруднений на хлебном фронте, смешали причины 
временные и конъюнктурные (специфические) с причинами длительными и основными»). Оппонентов из состава Политбюро Сталин не упомянул вообще. Сдержанное замечание о потенциальной возможности применения «чрезвычайных мер» в отношении кулаков и спекулянтов не вызвало каких-либо комментариев у слушателей, а заключительная фраза «...нынешние трудности закалят наши большевистские ряды...» [5, с. 362-369] - казалось, устраивала всех.

Чисто внешняя сдержанность Сталина была подхвачена Н.И. Бухариным. В своем выступлении «главный идеолог» партии несколько раз ссылался на слова генсека. Но слушатели могли заметить по меньшей мере три принципиальных отличия.

Рассматривая отношения города и села как преимущественно рыночные, из всех причин, породивших кризис хлебозаготовок, Бухарин на первое место поставил вопрос о ценах (произвольное понижение цен на сельскохозяйственные продукты) [5, с. 376-377]. Со всей определенностью Бухарин определил отказ от практики «чрезвычайных мер» как главнейшую задачу партии. Бухарин подчеркивал: «Мы должны снять эти чрезвычайные меры, потому что они переросли самих себя, они изжили себя исторически, они хозяйственно нам больше почти что ничего не дают» [5, с. 379].

Наконец модернизацию сельской экономики Бухарин видел в одновременном развитии индивидуального хозяйства, курса на коллективизацию и индустриализацию сельского производства, в дальнейшем «наступлении на кулака»; успехи планирования связывались с уходом от сверхцентрализации и заменой бюрократической инициативы инициативой с мест [5, с. 384, 389].

Судя по количеству реплик во время выступления Бухарина (как правило, поощрительных), участники пленума с одобрением отнеслись к содержанию доклада.

В исторической литературе последних десятилетий прочно утвердилось понятие «бухаринская альтернатива» как особое идейно-политическое направление в 1928-1929 гг., предложившее свой путь построения социализма [4, с. 122]. Тут следует отметить, что взгляды Бухарина переплетались с мнением многих советских экономистов, изложенным в научных статьях и монографиях середины 1920-х годов [13, с. 26-29], в проектах Первого пятилетнего плана на съездах плановых работников [11]. На пленуме же судя по количеству заданных вопросов и поданных реплик, по остроте выступления - сторонниками нэпа руководил все же не Бухарин, а Рыков.

Выступление В.М. Молотова фактически подводило черту под обсуждением вопроса о хлебозаготовках. Начало его доклада было выдержано в духе поддержки выводов Рыкова и Бухарина. «Из всей обстановки текущего момента вытекает, что ответ на вопрос о том, как кончить хлебозаготовительную кампанию 1927/28 г., должен состоять в решительной ликвидации чрез- 
вычайных мер в деревне, и притом ликвидации немедленной», - заявил секретарь ЦК. Совпадала и оценка причин возникших трудностей [5, с. 390-391]. С Углановым Молотов солидаризовался и в том, что сеть «частных мелких предприятий» свертывать не нужно [5, с. 390-391, 404].

Однако пламенный революционер в Молотове не угас. Нужный в конкретный исторический момент слой мелких предпринимателей все-таки должен был быть в итоге уничтоженным: «Нам не приходится надеяться на повышение дохода у частного капитала в городе и деревне, этот слой у нас гибнет, отживает, мы его умерщвляем и загоняем в могилу» [5, с. 397]. Отдавая должное образности слога секретаря ЦК, нельзя не заметить: за все время его пространного выступления ни разу не прозвучало слово «НЭП». Зато соратник Сталина неоднократно подвергал критике противников генсека - за «антимарксизм». Молотов довел градус дискуссии до нужной точки: отличные от сталинских подходы к достижению цели превращались во враждебные.

Обсуждение резолюции не принесло неожиданностей: сторонники НЭПа оказались в большинстве. Пленум подтвердил необходимость его сохранения, установку на подъем мелких и средних индивидуальных крестьянских хозяйств, на широкое использование и развитие товарно-рыночных связей в экономике. В резолюции говорилось об «опасности разрыва между городом и деревней», о том, что индивидуальное хозяйство «значительное время будет еще базой зернового хозяйства в стране», признавались ошибки при проведении хлебозаготовительной кампании 1927-1928 гг., провозглашалась недопустимость нового применения чрезвычайных мер [5, с. 588-592]. Вскоре были повышены (хотя и незначительно) заготовительные цены на хлеб [там же].

В предпоследний день работы пленума (11 июля 1928 г.) был заслушан доклад М.И. Калинина «Об организации новых (зерновых) совхозов». «Всесоюзный староста» начал с сообщения о том, что, по инициативе Сталина, 26 апреля 1928 г. было принято постановление Политбюро «об организации в течение 3-4 лет в РСФСР и на Украине новых крупных совхозов по производству хлеба... в расчете на то, чтобы к концу этого срока иметь в них годовое производство товарного хлеба в размере 100 млн пудов» [5, с. 453].

На организацию новых совхозов государством была выделена огромная сумма - 300 млн руб. О серьезности вопроса говорил и тот факт, что с апреля по июль 1928 г. комиссия Политбюро по организации новых совхозов собиралась 8 раз [5, с. 453-454]. Обсуждала комиссия и проблему машинизации новых совхозов. Однако здесь действительность была неутешительной: при необходимости иметь тракторный парк примерно в 25 тыс. тракторов тракторостроители в год выпускали 100-180 тракторов. Тем не менее отсутствие 
необходимых материально-технических предпосылок не должно было остановить создание новых совхозов [5, с. 457-458].

Судя по всему, тревожные мысли все-таки не оставляли Калинина. «Не проще ли, - задал он вопрос, - всю эту сумму денег бросить на уже существующие старые совхозы? Тем паче, защитников этой линии много». Однако старые совхозы, по его мнению, оказались малодейственными организациями с директивными методами управления и внеэкономическими методами хозяйствования [5, с. 463$]$.

Примечательно, что весь доклад «всесоюзный староста» фактически «ёрничал»: постоянно перемежевал речь шутками и задирал присутствующих колкими репликами. В тексте стенограммы выступления Калинина постоянно присутствует слово «смех». Однако «смешные настроения» быстро закончились, и участники пленума обрушились с резкой критикой на «шутника».

Тон задал Н.М. Анцелович, председатель ЦК профсоюза сельских рабочих, заметивший, что проект создания новых совхозов не учитывает очевидные риски: район, предполагаемый для строительства зерновых фабрик (Северный Кавказ), - засушливый; намечаемая система полеводства страдает элементами агроэкономической безграмотности. Все это приведет к нерентабельности совхозов и огромным растратам денег. Более того, продолжал профсоюзный работник: «Всякое крупное хозяйство, если оно не будет машинизировано в наших условиях, когда рабочий или крестьянский труд обходится очень дорого, будет нерентабельным» [5, с. 474]. Выступивший в прениях Осинский заявил, что из доклада Калинина «никаких деловых предложений не видно» [5, с. 482, 484]. Чубарь же утверждал, что Калинин «строит иллюзии», рассказывая о новых совхозах как о методах построения социализма в деревне [5, с. 489, 490].

Мнение Чубаря поддержало большинство выступающих по этому вопросу. О чрезвычайно тяжелом положении, убыточности старых совхозов РСФСР, огромной нехватке управленческих кадров для совхозов говорил заместитель наркома земледелия РСФСР И.Е. Клименко [5, с. 497-498, 509].

Для спасения Постановления Политбюро пришлось незапланированно выступать Сталину [5, с. 513]. В качестве главного объекта критики генсек избрал Осинского, методично доказывая его некомпетентность. Доводы Сталина о необходимости создания новых совхозов, помимо изложения опыта одного образцового зернового хозяйства в США, были основаны на лозунге обязательности «систематической поддержки крестьянской бедноты» [5, c. 513-518].

В предельно короткой резолюции пленума «Об организации новых совхозов» говорилось о необходимости тщательно отобрать земельные участки для этого предприятия - «чтобы обеспечить при минимуме риска наибольшую рентабельность этих предприятий». При строительстве новых предпола- 
галось максимально изучить опыт старых совхозов [5, с. 597-598]. Таким образом, Сталину удалось отклонить все аргументированные возражения участников пленума. Решение об организации «зерновых фабрик» в чрезвычайных масштабах и в чрезвычайном порядке все-таки было принято.

Сегодня известна и цена такого решения: как указывают специалистыаграрники, через четыре-пять лет, когда новые совхозы по плану уже должны были заработать на полную мощность, недород и голод 1932-1933 гг. сильнее всего поразили именно районы их размещения [3, с. 20].

Кто же одержал победу в ходе девятидневного политического противостояния на Июльском пленуме? Главный вопрос, вынесенный на обсуждение пленума ЦК, - о хлебозаготовках - завершился принятием резолюции, близкой по содержанию к тезисам группы Рыкова - Бухарина. Возможность продолжения новой экономической политики как доказавшей свою эффективность была признана участниками пленума.

Однако Сталин и его сторонники упорно отстаивали иное мнение. Прикрываясь резолюциями по первому, «коминтерновскому», вопросу, они использовали тезис об обострении классовой борьбы для обоснования потенциальной возможности применения чрезвычайных мер. Вопреки решениям пленумов, вне официальной политики правящей партии, начиняя с первых месяцев 1928 г. нарастает управляемая Сталиным кампания насилия со стороны органов ОГПУ и представителей местных советских и партийных структур. Это приводило к вполне определенным результатам: частнохозяйственные формы торговли и промышленности приобрели остаточный характер [3, с. 19].

Тем не менее значение Июльского пленума велико. На нем была продемонстрирована реальная альтернатива левацкому курсу - вариант осуществления индустриализации страны и преобразования крестьянской экономики на принципах новой экономической политики. Пленум продемонстрировал способность части большевистского руководства к восприятию рационального пути развития экономики, способность понять и осознать выводы ученыхэкономистов, просто проявить прагматизм исходя из опыта хозяйствования в регионах. В открытом и честном бою сталинизм не выдержал испытания.

Исключительная сложность реализации альтернативного сталинизму варианта развития СССР не вызывает сомнения. Вырваться из-под притяжения идеологических догм было предельно трудно [9, с. 419].

Прагматизм, однако, не был чужд марксистам в критические минуты их деятельности. Если осмысление практики сопоставлялось с доводами ученых появлялась возможность пройти и через «бутылочное горлышко» истории. И это - урок для современной России. Не осмыслив пути решения проблем НЭПовской экономики в конце 1920-х годов, она вновь сталкивается со слож- 
нейшими задачами взаимодействия «социального» государства и частного предпринимательства в условиях раннего капитализма.

\section{Библиография}

1. Верт Н. История Советского государства. 1900-1991. М.: Прогресс: ПрогрессАкадемия, 1992. 480 с.

2. Гимпельсон Е.Г. Новая экономическая политика Ленина - Сталина. Проблемы и уроки (20-е гг. XX в.). М.: Собрание, 2004. 303 с.

3. Данилов В.П., Ватлин А.Ю., Хлевнюк О.В. Введение // Как ломали НЭП. Стенограммы пленумов ЦК ВКП (б) 1928-1929 гг. В 5 т. М.: МФ «Демократия», 2000. Т. 2: Пленум ЦК ВКП (б) 4-12 июля 1928 г. С. 4-25.

4. Данилов В.П. История крестьянства России в XX веке // Данилов В.П. Избранные труды: в 2 ч. М.: РОССПЭН, 2011. Ч. 1. 863 с.

5. Как ломали НЭП. Стенограммы пленумов ЦК ВКП (б) 1928-1929 гг. В 5 т. М.: МФ «Демократия», 2000. Т. 2: Пленум ЦК ВКП (б) 4-12 июля 1928 г. 719 с.

6. Кислицын С.А. Председатель Совнаркома Советской России Сергей Сырцов: Из истории формирования антисталинского сопротивления в советском обществе в 1920-1930-е годы. М.: ЛЕНАНД, 2014. 264 с.

7. Кондрашин В.В. Хлебозаготовительная политика в годы первой пятилетки и ее результаты (1929-1933 гг.). М.: РОССПЭН, 2014. 350 с.

8. Кун М. Бухарин - его друзья и враги. М.: Республика, 1992. 480 с.

9. Панцев А.В. Дэн Сяопин. М.: Молодая гвардия, 2013. 558 с.

10. Перспективы развертывания народного хозяйства СССР на 1926-27-1930-31 гг.: Материалы Центральной комиссии по пятилетнему плану / Под ред. С.Г. Струмилина. М.: Госплан СССР, 1927. 699 с.

11. Проблемы реконструкции народного хозяйства на пятилетие (пятилетний перспективный план на пятом съезде советов госпланов). М.: Плановое хозяйство, 1929. 647 с.

12. Такер Р. Сталин. Путь к власти. 1879-1929. История и личность. М.: Прогресс, 1990. $480 \mathrm{c}$.

13. Ясный Н. Советские экономисты 1920-х годов. Долг памяти. М.: Дело, 2012. 344 с.

\section{References}

Vert N. Istorija Sovetskogo gosudarstva. 1900-1991. Moscow: Progress: Progress-Akademija, 1992. $480 \mathrm{p}$

Gimpel'son E.G. Novaja jekonomicheskaja politika Lenina - Stalina. Problemy i uroki (20-e gg. XX v.). Moscow: Sobranie, 2004. 303 p.

Danilov V.P., Vatlin A.Ju., Hlevnjuk O.V. Vvedenie // Kak lomali Njep. Stenogrammy plenumov CK VKP (b) 1928-1929 gg. V 5 t. Moscow: MF «Demokratija», 2000. Vol. 2: Plenum CK VKP (b) 4-12 ijulja 1928 g. P. 4-25.

Danilov V.P. Istorija krest'janstva Rossii v XX veke // Danilov V.P. Izbrannye trudy: v $2 \mathrm{ch}$. Moscow: ROSSPJeN, 2011. Chast' 1.863 p.

Kak lomali NJeP. Stenogrammy plenumov CK VKP (b) 1928-1929 gg. V 5 t. Moscow: MF «Demokratija», 2000. Vol. 2: Plenum CK VKP (b) 4-12 ijulja 1928 g. 719 p.

Kislicyn S.A. Predsedatel' Sovnarkoma Sovetskoj Rossii Sergej Syrcov: Iz istorii formirovanija antistalinskogo soprotivlenija v sovetskom obshhestve v 1920-1930-e gg. Moscow: LENAND, 2014. $264 \mathrm{p}$. 


\section{ФЕНОМЕНОЛОГИЯ СОВЕТСКОГО ОБЩЕСТВА}

Kondrashin V.V. Hlebozagotovitel'naja politika v gody pervoj pjatiletki i ee rezul'taty (19291933 gg.) Moscow: ROSSPJeN, 2014. 350 s.

Kun M. Buharin - ego druz'ja i vragi. Moscow: Respublika, 1992. 480 p.

Pancev A.V. Djen Sjaopin. Moscow: Molodaja gvardija, 2013. 558 p.

Perspektivy razvertyvanija narodnogo hozjajstva SSSR na 1926-27-1930-31 gg.: Materialy Central'noj komissii po pjatiletnemu planu / Pod red. S.G. Strumilina. Moscow: Gosplan SSSR, 1927. $699 \mathrm{p}$.

Problemy rekonstrukcii narodnogo hozjajstva na pjatiletie (pjatiletnij perspektivnyj plan na pjatom s'ezde sovetov gosplanov). Moscow: Planovoe hozjajstvo, 1929. 647 p.

Taker R. Stalin. Put' k vlasti. 1879-1929. Istorija i lichnost'. Moscow: Progress, 1990. 480 p.

Jasnyj N. Sovetskie jekonomisty 1920 godov. Dolg pamjati. Moscow: Delo, 2012. 344 p. 